\title{
Preparation, Characterization, and Antimicrobial Activities of Bimetallic Complexes of Sarcosine with Zn(II) and Sn(IV)
}

\author{
Yasir Arafat, ${ }^{1}$ Saqib Ali, ${ }^{2}$ Saira Shahzadi, ${ }^{1}$ and Muhammad Shahid ${ }^{3}$ \\ ${ }^{1}$ Department of Chemistry, GC University, Faisalabad 38000, Pakistan \\ ${ }^{2}$ Department of Chemistry, Quaid-i-Azam University, Islamabad 45320, Pakistan \\ ${ }^{3}$ Department of Chemistry and Biochemistry, University of Agriculture, Faisalabad 38000, Pakistan
}

Correspondence should be addressed to Saqib Ali; drsa54@yahoo.com and Saira Shahzadi; sairashahzadi@hotmail.com

Received 29 April 2013; Accepted 30 August 2013

Academic Editor: Claudio Pettinari

Copyright (c) 2013 Yasir Arafat et al. This is an open access article distributed under the Creative Commons Attribution License, which permits unrestricted use, distribution, and reproduction in any medium, provided the original work is properly cited.

\begin{abstract}
Heterobimetallic complexes of $\mathrm{Zn}(\mathrm{II})$ and $\mathrm{Sn}(\mathrm{IV})$ with sarcosine have been synthesized at room temperature under stirring conditions by the reaction of sarcosine and zinc acetate in $2: 1$ molar ratio followed by the stepwise addition of $\mathrm{CS}_{2}$ and organotin(IV) halides, where $\mathrm{R}=\mathrm{Me}, n$ - $\mathrm{Bu}$, and $\mathrm{Ph}$. The complexes were characterized by elemental analysis, FT-IR and NMR $\left({ }^{1} \mathrm{H}\right.$, $\left.{ }^{13} \mathrm{C}\right)$ spectroscopy. IR data showed that the ligand acts in a bidentate manner. NMR data revealed the four coordinate geometry in solution state. In vitro antimicrobial activities data showed that complexes (3) and (4) were effective against bacterial and fungal strains with few exceptions.
\end{abstract}

\section{Introduction}

Organotin compounds are amongst the most widely used organometallic compounds. Over the last several decades, they have been utilized for a variety of industrial and agricultural applications including pesticides, fungicide, and antifouling agents [1]. In general, the biochemical activity of organotin(IV) carboxylates is greatly influenced by the structure of the molecule and the coordination number of the tin atom $[2,3]$. Therefore, the recognition of the importance between the biological properties and the structure of organotin(IV) carboxylates [4] has stimulated the study of carboxylates of tin.

The diverse structural motifs are known in organotin compounds and attributed to the ambidentate character of the carboxylate ligands [5]. Steric and electronic attributes of organic substituents on tin and/or the carboxylate moiety impart significant influence on the structural characteristics in tin carboxylates. Therefore, synthesis of new organotin carboxylates with different structural features will be beneficial in the development of pharmaceutical organotin and in other properties and applications.
Meanwhile, dithiocarbamate (DTC) is the ligand which strongly bonds with metal ions and can stabilize metal complexes with high oxidation number [6]. Organotin(IV) dithiocarbamate complexes have been widely studied due to $\mathrm{Sn}-\mathrm{S}$ bond in their structure and the effects of the bonding on diversified applications basically in biological field $[7,8]$.

Zinc chloride is chiefly used as a catalyst for the Fischer indole synthesis and Friedel-Craft acylation reaction that was involved in the synthesis of organic compounds used in the laboratory [9]. The medical applications of $\mathrm{Zn}$ (II) compounds include treatments of parasitic diseases (eczema, ringworm, fungus, and athletes foot), and in many biological processes zinc plays an important role as metalloenzymes in which $\mathrm{Zn}(\mathrm{II})$ is coordinated by a ligand that leads to a structural as well as functional model [10].

In our previous work, we reported several organotin complexes with oxygen and sulfur donor atoms [11-15]. As an extension of this research program, we report here the complexes of sarcosine (Figure 1) containing $\mathrm{Zn}$ (II) and $\mathrm{Sn}(\mathrm{IV})$ to study the effect of $\mathrm{Zn}$ along with tin on biological activities and compare these results with already reported organotin complexes of sarcosine [16-18]. 


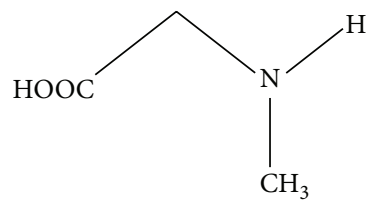

FIGURE 1: Chemical structure of sarcosine.

These complexes were characterized by elemental analysis, IR and multinuclear NMR $\left({ }^{1} \mathrm{H},{ }^{13} \mathrm{C}\right)$. These were also examined to check their antibacterial and antifungal activity in vitro.

\section{Experimental}

2.1. Materials and Methods. N-Methyl glycine (sarcosine), zinc acetate, carbon disulfide, and organotin(IV) halides were of Sigma-Aldrich (UK) origin. The organic solvents (chloroform, $n$-hexane, ethanol, methanol, DMSO, and acetone) were procured from Merck (Germany). The solvents were dried [19] prior to use. Nutrient broth, nutrient agar, and potato dextrose agar were of oxide (UK) origin. Autoclave and laminar air flow were purchased from Omron and Dalton companies of Japan, respectively. Micropipettes were purchased from Gilson (France). The melting points were determined on an electrothermal melting point apparatus, model Staurt SMP3 by using capillary tubes. Elemental analysis was done for carbon, hydrogen, nitrogen, and sulphur on a CHNS-932 elemental analyzer Leco Corporation (USA). The infrared spectra were recorded as $\mathrm{KBr}$ pellets on Perkin Elmer 1000 spectrometer in the frequency range of $4000-250 \mathrm{~cm}^{-1}$. NMR $\left({ }^{1} \mathrm{H}\right.$ and $\left.{ }^{13} \mathrm{C}\right)$ spectra were recorded on Bruker AM$300 \mathrm{MHz}$ FT-NMR spectrometer (Germany) using $\mathrm{CDCl}_{3}$ as an internal reference.

2.2. General Procedure for the Synthesis of Complexes. Sarcosine $(0.178 \mathrm{~g}, 2 \mathrm{mmol})$ was dissolved in methanol $(25 \mathrm{~mL})$ in a round bottom flask with continuous stirring at room temperature. Then solution of zinc acetate $(0.22 \mathrm{~g}, 1 \mathrm{mmol})$ in methanol $(3 \mathrm{~mL})$ was added dropwise to the above solution, and mixture was stirred continuously for 20 minutes. After that $\mathrm{CS}_{2}(0.120 \mathrm{~mL}, 2.0 \mathrm{mmol})$ in methanol $(5 \mathrm{~mL})$ was added dropwise to the reaction mixture and stirred for $0.5 \mathrm{hr}$ at room temperature. Subsequently, the solution of diorganotin dichloride/triorganotin chloride $(2 \mathrm{mmol})$ in methanol $(50 \mathrm{~mL})$ was added and the mixture was continuously stirred for $4 \mathrm{hr}$. Solvent was slowly evaporated at room temperature and product obtained was dried in air. Purity was checked by TLC and recrystallization was done in methanol: $n$-hexane $(1: 1)$ (see Scheme 1).

\section{Results and Discussion}

The ligand and synthesized complexes are solid and stable in air. They have sharp melting points. Elemental analysis was done to compare the observed values with predicted values of percentage of the carbon, hydrogen, nitrogen, and sulfur.
The physical data of ligand and synthesized complexes is summarized in Table 1.

3.1. Infrared Spectroscopy. IR spectra of the ligand and its newly synthesized complexes (1)-(6) were recorded as $\mathrm{KBr}$ pellets in the range of $4000-250 \mathrm{~cm}^{-1}$. The characteristic infrared absorption frequencies $\left(\mathrm{cm}^{-1}\right)$ have been listed in Table 2.

The IR spectrum of the ligand exhibited a band at $3365 \mathrm{~cm}^{-1}$, which was attributed to the NH stretching mode. Deprotonation of carboxylic group is confirmed by the absence of $\mathrm{OH}$ band in the spectra of the complexes. Regarding the carboxyl vibrational modes, there are different binding possibilities [20, 21]:

(1) bridged structure, $v_{s}(\mathrm{COO})=1560-1540 \mathrm{~cm}^{-1}$,

(2) dimer and monomer chelate structures, $v_{a}(\mathrm{COO})=$ $1640-1560 \mathrm{~cm}^{-1}$,

(3) "free ester" monodentate structure, $v(\mathrm{C}-\mathrm{O})=1680-$ $1640 \mathrm{~cm}^{-1}$ and $\nu(\mathrm{C}=\mathrm{O})=17701700 \mathrm{~cm}^{-1}$.

The carboxylate group gives strong asymmetric and symmetric stretching bands in the range of $1602-1650 \mathrm{~cm}^{-1}$ and 1433$1470 \mathrm{~cm}^{-1}$, respectively, and it is assignable to a chelate or monodentate structure; however, the absence of $\nu \mathrm{C}=\mathrm{O}$ band in expected range is indicative of the presence of the chelate form. Bidentate nature of ligand is also confirmed by $\Delta \nu \mathrm{COO}$ value that is less than $200 \mathrm{~cm}^{-1}$ in all complexes [22]. Presence of $v \mathrm{Zn}-\mathrm{O}$ vibrational bands in the range of $310-385 \mathrm{~cm}^{-1}$ in all the complexes [23] confirms the zinc carboxylate interaction. It has been reported [15] that the observation of a single $\nu \mathrm{C}=\mathrm{S}$ absorption in the region around $1000 \mathrm{~cm}^{-1}$ is indicative of dithiocarbamate groups that are bonded symmetrically or bidentate in nature. A strong absorption band of $v(\mathrm{C}=\mathrm{S})$ lies in the range of $1013-1043 \mathrm{~cm}^{-1}$, while $\nu(\mathrm{C}-\mathrm{S})$ band appears in the lower frequency range, 942$988 \mathrm{~cm}^{-1}$ [24]. The $\mathrm{Sn}-\mathrm{S}$ bond formation is confirmed by the appearance of a new band in the range of $456-480 \mathrm{~cm}^{-1}$ [25]. The strong band at $302-318 \mathrm{~cm}^{-1}$ was assigned to $\nu(\mathrm{Sn}-$ $\mathrm{Cl})$ absorption. The $\mathrm{Sn}-\mathrm{C}$ band was observed in the range of $530-547 \mathrm{~cm}^{-1}$ for complexes (1) and (2)-(5) but at 272 and $280 \mathrm{~cm}^{-1}$ for complexes (3) and (4), respectively, which are di- and triphenyltin derivatives. The absence of the band in the range $440-420 \mathrm{~cm}^{-1}$ which is commonly assigned to the $v(\mathrm{Sn}-\mathrm{N})$ mode in analogous compounds $[26,27]$ rules out amino coordination to tin, thus leading support to the proposed carboxylate carboxyl atom [16] and dithiolate sulphur atom coordination in all synthesized complexes.

3.2. ${ }^{1} H$ NMR Spectroscopy. ${ }^{1} \mathrm{H}$ NMR spectra of the ligand and complexes (1)-(6) were recorded in deuterated DMSO to find the behaviour of magnetically nonequivalent protons. The data is presented in Table 3.

The number of protons calculated by integration of peaks is in excellent agreement with those theoretically calculated by incremental method [28]. The absence of $\mathrm{OH}$ signal in the complex suggested the deprotonation of carboxylic acid group for $\mathrm{O} \rightarrow \mathrm{Zn}$ coordination through $\mathrm{COO}^{-}$anions. 
2 HOOC $\left.\right|_{\mathrm{CH}_{3}} ^{\mathrm{H}}+\mathrm{Zn}\left(\mathrm{CH}_{3} \mathrm{COO}\right)_{2}$<smiles></smiles>

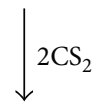<smiles></smiles>

$2 \mathrm{R}_{2} \mathrm{SnCl} / 2 \mathrm{R}_{3} \mathrm{SnCl}$<smiles></smiles>

$\mathrm{X}$ : $\mathrm{Cl}$ for diorganotin

$\mathrm{X}$ : R for triorganotin

$\mathrm{R}: \mathrm{Me}, n-\mathrm{Bu}, \mathrm{Ph}$

\begin{tabular}{|c|c|c|c|}
\hline $\mathrm{R}_{2} \mathrm{Cl}$ & $\mathrm{Me}$ & $n-\mathrm{Bu}$ & $\mathrm{Ph}$ \\
\hline Compound number & $\mathbf{( 1 )}$ & $\mathbf{( 2 )}$ & $\mathbf{( 3 )}$ \\
\hline $\mathrm{R}_{3}$ & $\mathrm{Me}$ & $n-\mathrm{Bu}$ & $\mathrm{Ph}$ \\
\hline Compound number & $\mathbf{( 4 )}$ & $\mathbf{( 5 )}$ & $\mathbf{( 6 )}$ \\
\hline
\end{tabular}

SCHEME 1

TABle 1: Physical data of heterobimetallic complexes with sarcosine.

\begin{tabular}{|c|c|c|c|c|c|c|c|c|}
\hline \multirow[b]{2}{*}{$\begin{array}{l}\text { Comp. } \\
\text { no. }\end{array}$} & \multirow[b]{2}{*}{ Molecular formula } & \multirow[b]{2}{*}{ Mol. weight } & \multirow[b]{2}{*}{$\%$ yield } & \multirow[b]{2}{*}{ m.p $\left({ }^{\circ} \mathrm{C}\right)$} & \multicolumn{4}{|c|}{ Elemental analysis } \\
\hline & & & & & $\begin{array}{c}\% \mathrm{C} \\
\text { Calcd. } \\
\text { (found) }\end{array}$ & $\begin{array}{c}\% \mathrm{H} \\
\text { Calcd. } \\
\text { (found) }\end{array}$ & $\begin{array}{c}\% \mathrm{~N} \\
\text { Calcd. } \\
\text { (found) }\end{array}$ & $\begin{array}{c}\% \mathrm{~S} \\
\text { Calcd. } \\
\text { (found) }\end{array}$ \\
\hline HL & $\mathrm{C}_{3} \mathrm{H}_{7} \mathrm{O}_{2} \mathrm{~N}$ & 89.09 & - & 208 & $\begin{array}{c}40.45 \\
(40.42)\end{array}$ & $\begin{array}{c}7.92 \\
(7.95)\end{array}$ & $\begin{array}{c}15.71 \\
(15.68)\end{array}$ & - \\
\hline (1) & $\mathrm{C}_{12} \mathrm{H}_{22} \mathrm{O}_{4} \mathrm{~N}_{2} \mathrm{~S}_{4} \mathrm{Cl}_{2} \mathrm{ZnSn}_{2}$ & 760.31 & 75 & $121-122$ & $\begin{array}{c}18.95 \\
(18.99)\end{array}$ & $\begin{array}{c}2.91 \\
(2.95)\end{array}$ & $\begin{array}{c}3.68 \\
(3.64)\end{array}$ & $\begin{array}{c}16.87 \\
(16.89)\end{array}$ \\
\hline (2) & $\mathrm{C}_{24} \mathrm{H}_{46} \mathrm{O}_{4} \mathrm{~N}_{2} \mathrm{~S}_{4} \mathrm{Cl}_{2} \mathrm{ZnSn}_{2}$ & 928.63 & 68 & $87-91$ & $\begin{array}{c}31.04 \\
(31.07)\end{array}$ & $\begin{array}{c}4.99 \\
(4.96)\end{array}$ & $\begin{array}{c}3.01 \\
(3.04)\end{array}$ & $\begin{array}{c}13.81 \\
(13.78)\end{array}$ \\
\hline (3) & $\mathrm{C}_{32} \mathrm{H}_{30} \mathrm{O}_{4} \mathrm{~N}_{2} \mathrm{~S}_{4} \mathrm{Cl}_{2} \mathrm{ZnSn}_{2}$ & 1008.53 & 57 & $107-109$ & $\begin{array}{c}38.10 \\
(39.12)\end{array}$ & $\begin{array}{c}2.99 \\
(2.96)\end{array}$ & $\begin{array}{c}2.77 \\
(2.74)\end{array}$ & $\begin{array}{c}12.71 \\
(12.74)\end{array}$ \\
\hline (4) & $\mathrm{C}_{14} \mathrm{H}_{28} \mathrm{O}_{4} \mathrm{~N}_{2} \mathrm{~S}_{4} \mathrm{ZnSn}_{2}$ & 719.61 & 67 & $145-146$ & $\begin{array}{l}23.36 \\
(23.39)\end{array}$ & $\begin{array}{c}3.92 \\
(3.96)\end{array}$ & $\begin{array}{c}3.89 \\
(3.92)\end{array}$ & $\begin{array}{c}17.82 \\
(17.78)\end{array}$ \\
\hline (5) & $\mathrm{C}_{32} \mathrm{H}_{64} \mathrm{O}_{4} \mathrm{~N}_{2} \mathrm{~S}_{4} \mathrm{ZnSn}_{2}$ & 971.53 & 51 & $224-225$ & $\begin{array}{c}39.55 \\
(39.50)\end{array}$ & $\begin{array}{c}6.64 \\
(6.68)\end{array}$ & $\begin{array}{c}2.88 \\
(2.85)\end{array}$ & $\begin{array}{c}13.20 \\
(13.17)\end{array}$ \\
\hline (6) & $\mathrm{C}_{44} \mathrm{H}_{40} \mathrm{O}_{4} \mathrm{~N}_{2} \mathrm{~S}_{4} \mathrm{ZnSn}_{2}$ & 1091.89 & 73 & $86-88$ & $\begin{array}{c}48.39 \\
(48.36)\end{array}$ & $\begin{array}{c}3.69 \\
(3.65)\end{array}$ & $\begin{array}{c}2.56 \\
(2.59)\end{array}$ & $\begin{array}{c}11.74 \\
(11.78)\end{array}$ \\
\hline
\end{tabular}


TABLE 2: IR spectral data $\left(\mathrm{cm}^{-1}\right)$ of heterobimetallic complexes with sarcosine.

\begin{tabular}{|c|c|c|c|c|c|c|c|c|c|c|}
\hline \multirow{2}{*}{ Comp no. } & \multirow{2}{*}{$\nu(\mathrm{NH})$} & \multicolumn{2}{|c|}{$v(\mathrm{COO})$} & \multirow{2}{*}{$\Delta v$} & \multirow{2}{*}{$\nu(\mathrm{C}=\mathrm{S})$} & \multirow{2}{*}{$\nu(\mathrm{C}-\mathrm{S})$} & \multirow{2}{*}{$\nu(\mathrm{Sn}-\mathrm{C})$} & \multirow{2}{*}{$v(\mathrm{Sn}-\mathrm{S})$} & \multirow{2}{*}{$\nu(\mathrm{Sn}-\mathrm{Cl})$} & \multirow{2}{*}{$v(\mathrm{Zn}-\mathrm{O})$} \\
\hline & & $v(\mathrm{COO})($ asym $)$ & $v(\mathrm{COO})(\mathrm{sym})$ & & & & & & & \\
\hline $\mathrm{HL}$ & 3365 & 1621 & 1407 & 214 & - & - & - & - & - & - \\
\hline (1) & - & 1642 & 1462 & 180 & 1033 & 955 & 526 & 461 & 311 & 364 \\
\hline (2) & - & 1618 & 1433 & 185 & 1013 & 942 & 530 & 472 & 302 & 352 \\
\hline (3) & - & 1602 & 1440 & 162 & 1025 & 988 & 272 & 466 & 318 & 347 \\
\hline (4) & - & 1622 & 1456 & 166 & 1023 & 938 & 538 & 485 & - & 371 \\
\hline (5) & - & 1635 & 1468 & 167 & 1043 & 965 & 547 & 456 & - & 385 \\
\hline (6) & - & 1650 & 1470 & 180 & 1030 & 970 & 280 & 480 & - & 310 \\
\hline
\end{tabular}

TABLE 3: ${ }^{1} \mathrm{H}$ NMR data ${ }^{\mathrm{a}-\mathrm{d}}$ (ppm) of heterobimetallic complexes with sarcosine.

\begin{tabular}{lccccccc}
\hline Proton no. & HL & $(\mathbf{1})$ & $(\mathbf{2})$ & $(\mathbf{3})$ & $\mathbf{( 4 )}$ & $\mathbf{( 5 )}$ & $(\mathbf{6})$ \\
\hline $2,2^{\prime}$ & $3.15 \mathrm{~s}$ & $3.97 \mathrm{~s}$ & $3.99 \mathrm{~s}$ & $3.88 \mathrm{~s}$ & $3.74 \mathrm{~s}$ & $3.63 \mathrm{~s}$ & $3.95 \mathrm{~s}$ \\
$3,3^{\prime}$ & $2.48 \mathrm{~s}$ & $2.89 \mathrm{~s}$ & $2.80 \mathrm{~s}$ & $2.96 \mathrm{~s}$ & $2.85 \mathrm{~s}$ & $2.94 \mathrm{~s}$ & $2.79 \mathrm{~s}$ \\
\hline
\end{tabular}

${ }^{a}$ Compound (1) Sn- $\mathrm{CH}_{3} \mathrm{Cl}, 1.27 \mathrm{~s}^{2} J[96]$; compound (2) Sn- $\mathrm{CH}_{2} \mathrm{CH}_{2} \mathrm{CH}_{2} \mathrm{CH}_{3} \mathrm{Cl}, 0.88-0.93 \mathrm{~m}, 0.23 \mathrm{t}$ (7.2); compound (3) $\mathrm{Sn}-\mathrm{C}_{6} \mathrm{H}_{5} \mathrm{Cl}, 7.91 \mathrm{~d}{ }^{2} J[82], 7.50-7.53 \mathrm{~m}$, 7.42-7.50m; compound (4) Sn- $\mathrm{CH}_{3}, 0.51 \mathrm{~s}^{2} J[82]$; compound (5) $\mathrm{Sn}_{-}-\mathrm{CH}_{2} \mathrm{CH}_{2} \mathrm{CH}_{2} \mathrm{CH}_{3}, 0.64-1.1 \mathrm{~m}, 0.23 \mathrm{t}$ (7.2); compound (6) Sn- $\mathrm{C}_{6} \mathrm{H}_{5}, 7.91 \mathrm{~d}^{2} J[82]$, 7.50-7.53m, $7.42-7.50 \mathrm{~m}$.

${ }^{\mathrm{b}}$ Multiplicity is given as s: singlet, d: doublet, t: triplet, m: multiplet.

${ }^{c}$ Coupling constant, ${ }^{n} J\left[{ }^{119} \mathrm{Sn},{ }^{1} \mathrm{H}\right]$ and ${ }^{n} J\left[{ }^{1} \mathrm{H},{ }^{1} \mathrm{H}\right]$ in $\mathrm{Hz}$ are given in square bracket and parenthesis, respectively.<smiles>CN(C)CC1=[Te]2O[Te](CN(C)C)(O1)O2</smiles>

TABLE $4:{ }^{13} \mathrm{C}$ NMR data ${ }^{\mathrm{a}, \mathrm{b}}$ (ppm) of heterobimetallic $\mathrm{Zn}(\mathrm{II})$ and $\mathrm{Sn}(\mathrm{IV})$ complexes with sarcosine.

\begin{tabular}{lccccccc}
\hline Carbon & HL & $(\mathbf{1})$ & $(\mathbf{2})$ & $(\mathbf{3})$ & $(\mathbf{4})$ & $(\mathbf{5})$ & $(\mathbf{6})$ \\
\hline $1,1^{\prime}$ & 179.2 & 186.3 & 181.9 & 183.7 & 185.4 & 184.3 & 183.8 \\
$2,2^{\prime}$ & 56.6 & 56.8 & 56.3 & 56.9 & 56.7 & 56.6 & 56.8 \\
$3,3^{\prime}$ & 41.5 & 41.3 & 41.3 & 41.5 & 41.4 & 41.2 & 41.5 \\
-CSS & - & 202.6 & 202.5 & 202.8 & 201.7 & 202.8 & 202.7 \\
\hline
\end{tabular}

${ }^{a}$ Compound (1) Sn- $\mathrm{CH}_{3} \mathrm{Cl}$, (C- $\left.\alpha\right) 2.1{ }^{1} J[397]$; compound (2) Sn$\mathrm{CH}_{2} \mathrm{CH}_{2} \mathrm{CH}_{2} \mathrm{CH}_{3} \mathrm{Cl}$, (C- $\left.\alpha\right) 29.5$, (C- $\left.\beta\right)$ 27.4, (C- $\left.\gamma\right)$ 26.2, (C- $\delta$ ) 13.9; compound (3) Sn- $\mathrm{C}_{6} \mathrm{H}_{5} \mathrm{Cl},(\mathrm{C}-\alpha) 137.6{ }^{1} J[640],(\mathrm{C}-\beta) 132.8^{2} J[49.0],(\mathrm{C}-\gamma)$ 129.9, (C- $\delta$ ) 124.8; compound (4) $\mathrm{Sn}-\mathrm{CH}_{3},(\mathrm{C}-\alpha) 2.3^{1} \mathrm{~J}[396]$; compound (5) $\mathrm{Sn}-\mathrm{CH}_{2} \mathrm{CH}_{2} \mathrm{CH}_{2} \mathrm{CH}_{3}$, (C- $\left.\alpha\right) 31.1$ [349], (C- $\left.\beta\right) 27.1{ }^{2}$ J[21], (C- $\left.\gamma\right) 28.2$ ${ }^{3} J[63]$, (C- $\delta$ ) 14.1; compound (6) Sn- $\mathrm{C}_{6} \mathrm{H}_{5},(\mathrm{C}-\alpha) 138.0^{1} J[640],(\mathrm{C}-\beta) 133.0$ ${ }^{2} J[49.0],(\mathrm{C}-\gamma)$ 130.0, (C- $\delta$ ) 125.1.

${ }^{\mathrm{b}} \mathrm{Chemical}$ shifts $(\delta)$ in ppm: ${ }^{n} J\left[{ }^{119} \mathrm{Sn},{ }^{13} \mathrm{C}\right]$ in $\mathrm{Hz}$ is listed in parenthesis.

Two resonance signals appeared as a singlet at $3.15 \mathrm{ppm}$ and $2.48 \mathrm{ppm}$ for the methylene and methyl protons, respectively, in the free ligand. These signals exhibited downfield shift to 3.63-3.99 ppm and 2.79-2.96 ppm in the complexes (1)-(6) for methylene and methyl protons, respectively.

The $\mathrm{CH}_{3}$ protons in compound (1) appear as a singlet at $1.27 \mathrm{ppm}$ with tin satellites having ${ }^{2} J\left[{ }^{119} \mathrm{Sn}-{ }^{1} \mathrm{H}\right]=96 \mathrm{~Hz}$. In compound (2), the protons of butyl group appear as a multiplet in the region $0.88-0.93 \mathrm{ppm}$. The terminal $\mathrm{CH}_{3}$ group of butyl gives triplet at $0.23 \mathrm{ppm}$ with ${ }^{3} J\left[{ }^{1} \mathrm{H}-{ }^{1} \mathrm{H}\right]$ value of $7.2 \mathrm{~Hz}$. The proton chemical shift of the methyl group in compound (3), attached to the Sn, gives a singlet at $0.51 \mathrm{ppm}$.
The phenyl moieties of di- and triphenyltin(IV) derivatives show a complex pattern and were assigned according to the literature [29]. The ${ }^{2} J\left[{ }^{119} \mathrm{Sn}-{ }^{1} \mathrm{H}\right]$ value for di- and triphenyltin(IV) derivatives is $82 \mathrm{~Hz}$, in the range expected for pentacoordinated tin atom, and consistent with $\mathrm{C}-\mathrm{Sn}-\mathrm{C}$ angle of $126.5^{\circ}$.

3.3. ${ }^{13} \mathrm{C} \mathrm{NMR}$. The assignments of -CSS group in investigated compounds is straightforward which are observed in the range of 202.5-202.8 ppm indicating the coordination of sulfur to the tin atom.

Table 4 lists the chemical shifts of ${ }^{13} \mathrm{C}$ and tin-carbon coupling constants for the reported complexes (1)-(6). The ${ }^{13} \mathrm{C}$ NMR chemical shifts due to the phenyl groups are observed at positions comparable to other similar compounds [30, 31]. The ${ }^{13} \mathrm{C}$ NMR chemical shift due to -COO carbon atom is observed at $179.2 \mathrm{ppm}$ in the free ligand while in the complexes it exhibits downfield shift in the range 181.9-186.3 ppm. Coordination of the tin atom in diand triorganotin has been related to ${ }^{n} J\left({ }^{119} \mathrm{Sn}-{ }^{13} \mathrm{C}\right)$ coupling constants. The ${ }^{n} J\left({ }^{119} \mathrm{Sn}-{ }^{13} \mathrm{C}\right)$ coupling for complexes (1) and (6) is 397 and $640 \mathrm{~Hz}$, respectively, which is indicative of four coordinate geometry [30] in solution state.

3.4. Antibacterial Activity. Sarcosine and synthesized complexes (1)-(6) were tested in vitro for their antibacterial activity against gram positive and gram negative bacterial 
TABle 5: Antibacterial activity data ${ }^{\mathrm{a}-\mathrm{e}}$ of complexes and ligand against selected bacterial strains.

\begin{tabular}{lcccc}
\hline Compound no. & \multicolumn{2}{c}{ Bacterial inhibition zone $(\mathrm{mm})$} \\
& S. aureus & B. subtilis & E. coli & P. multocida \\
\hline $\mathrm{HL}$ & $12.5^{\mathrm{c}} \pm 0.86$ & $13.0^{\mathrm{c}} \pm 1.00$ & $12.5^{\mathrm{c}} \pm 0.86$ & $12.0^{\mathrm{c}} \pm 1.41$ \\
$(\mathbf{1})$ & $20.8^{\mathrm{bc}} \pm 1.00$ & $18.0^{\mathrm{c}} \pm 1.00$ & $25.2^{\mathrm{c}} \pm 0.86$ & $21.0^{\mathrm{ab}} \pm 1.00$ \\
$(\mathbf{2})$ & $21.0^{\mathrm{bc}} \pm 1.00$ & $20.5^{\mathrm{bc}} \pm 0.86$ & $27.5^{\mathrm{bc}} \pm 0.86$ & $24.5^{\mathrm{ab}} \pm 0.86$ \\
$(\mathbf{3})$ & $20.8^{\mathrm{bc}} \pm 1.00$ & $18.6^{\mathrm{c}} \pm 1.00$ & $26.2^{\mathrm{c}} \pm 0.86$ & $21.3^{\mathrm{ab}} \pm 1.00$ \\
$(\mathbf{4})$ & $30.0^{\mathrm{ab}} \pm 1.41$ & $21.5^{\mathrm{bc}} \pm 1.65$ & $28.0^{\mathrm{bc}} \pm 1.41$ & $23.0^{\mathrm{ab}} \pm 1.00$ \\
$(\mathbf{5})$ & $32.5^{\mathrm{ab}} \pm 1.65$ & $54.5^{\mathrm{a}} \pm 0.86$ & $51.0^{\mathrm{a}} \pm 1.00$ & $32.5^{\mathrm{a}} \pm 1.65$ \\
$(\mathbf{6})$ & $31.5^{\mathrm{ab}} \pm 0.86$ & $33.0^{\mathrm{bc}} \pm 1.41$ & $32.0^{\mathrm{ab}} \pm 1.00$ & $30.0^{\mathrm{ab}} \pm 1.41$ \\
Ampicillin & $38.5^{\mathrm{a}} \pm 0.86$ & $40.0^{\mathrm{ab}} \pm 1.41$ & $39.5^{\mathrm{ab}} \pm 0.86$ & $32.0^{\mathrm{ab}} \pm 1.41$ \\
\hline
\end{tabular}

${ }^{\mathrm{a}}$ Concentration: $1 \mathrm{mg} / \mathrm{mL}$ in DMSO.

${ }^{\mathrm{b}}$ Standard: ampicillin.

${ }^{c} 0$ : no activity, 5-10: activity present, 11-25: moderate activity, 26-40: strong activity.

${ }^{\mathrm{d}}$ Antibacterial values are mean \pm S.D of samples analyzed individually in triplicate at $P<0.1$.

${ }^{\mathrm{e}}$ Different letters in superscript indicate significant differences.

TABle 6: Antifungal activity data ${ }^{\mathrm{a}-\mathrm{e}}$ of complexes and ligand against selected fungal strains.

\begin{tabular}{lcccc}
\hline Compound no. & \multicolumn{3}{c}{ Fungal inhibition zone (mm) } \\
& A. alternata & G. lucidum & A. flavus & A. niger \\
\hline HL & $27.0^{\mathrm{ab}} \pm 1.00$ & $11.5^{\mathrm{c}} \pm 0.86$ & $37.5^{\mathrm{ab}} \pm 0.86$ & $14.5^{\mathrm{bc}} \pm 1.65$ \\
$(\mathbf{1})$ & $26.4^{\mathrm{ab}} \pm 1.00$ & $19.3^{\mathrm{bc}} \pm 1.00$ & $20.2^{\mathrm{bc}} \pm 1.65$ & $20.3^{\mathrm{ab}} \pm 0.86$ \\
$(\mathbf{2})$ & $20.0^{\mathrm{c}} \pm 1.41$ & $19.0^{\mathrm{bc}} \pm 1.00$ & $20.5^{\mathrm{bc}} \pm 1.65$ & $20.5^{\mathrm{bc}} \pm 0.86$ \\
$(\mathbf{3})$ & $26.9^{\mathrm{bc}} \pm 1.41$ & $20.2^{\mathrm{ab}} \pm 1.65$ & $35.2^{\mathrm{bc}} \pm 1.65$ & $21.2^{\mathrm{bc}} \pm 0.86$ \\
$(\mathbf{4})$ & $30.0^{\mathrm{ab}} \pm 1.41$ & $18.5^{\mathrm{bc}} \pm 0.86$ & $19.5^{\mathrm{c}} \pm 1.65$ & $18.5^{\mathrm{bc}} \pm 0.86$ \\
$(\mathbf{5})$ & $30.0^{\mathrm{ab}} \pm 1.41$ & $39.5^{\mathrm{ab}} \pm 1.65$ & $37.0^{\mathrm{ab}} \pm 1.65$ & $33.5^{\mathrm{a}} \pm 1.65$ \\
$(\mathbf{6})$ & $28.5^{\mathrm{ab}} \pm 0.86$ & $25.0^{\mathrm{bc}} \pm 1.00$ & $32.0^{\mathrm{bc}} \pm 1.41$ & $19.5^{\mathrm{bc}} \pm 0.86$ \\
Fluconazole & $30.5^{\mathrm{a}} \pm 0.86$ & $41.5^{\mathrm{a}} \pm 0.86$ & $54.0^{\mathrm{a}} \pm 1.41$ & $12.5^{\mathrm{c}} \pm 0.86$ \\
\hline
\end{tabular}

${ }^{\mathrm{a}}$ Concentration: $1 \mathrm{mg} / \mathrm{mL}$ in DMSO.

${ }^{\mathrm{b}}$ Standard: fluconazole.

${ }^{c} 0$ : no activity, 5-10: activity present, 11-25: moderate activity, 26-40: strong activity.

${ }^{\mathrm{d}}$ Antibacterial values are mean \pm S.D of samples analyzed individually in triplicate at $P<0.1$.

${ }^{\mathrm{e}}$ Different letters in superscript indicate significant differences.

strains including B. subtilis and S. aureus and P. multocida and E. coli, respectively, and the results are given in Table 5. Ampicillin was used as a standard drug. The results revealed that all the newly synthesized complexes show higher activity than the ligand but markedly lower than the standard drug with few exceptions.

Complex (5) showed maximum inhibitory action against B. subtilis $(54.5 \pm 0.86)$ and E. coli $(51.0 \pm 1.00)$, probably more than standard drug $(40.00 \pm 1.41)$ and $(39.5 \pm 0.86)$, respectively. Complex (2) displayed lowest inhibition zone in case of B. subtilis $(20.5 \pm 0.86)$ and $S$. aureus $(21.0 \pm 1.00)$. The ligand exhibited low activities, while the complexes exhibited moderate activities as compared to standard drug towards all the bacterial strains. Complex (6) showed moderate antibacterial activity against all the bacterial strains. Among all the complexes, the tributyltin complex (5) showed significant antibacterial activity. It was clear from the data that antimicrobial activities varied according to substitution (increase in substitution on the Sn(IV) enhances the antimicrobial activity) [32].
Data revealed that the synthesized complexes showed more activity against gram positive bacterial strain than gram negative strains. It was due to the difference in the composition of cell wall of both the gram positive and gram negative strains [33]. It was also suggested that the antimicrobial activity of the complexes was either due to killing of microbes or inhibiting their reproduction by blocking their active sites [34].

The results show that all compounds exhibit antibacterial activity, and in many cases, complexes are more potent in their inhibition properties than the free ligand. This can be explained in terms of the greater lipid solubility and cellular penetration of the complexes [35]. It is clear that the coordination enhances the antibacterial activity and clearly indicates that the newly synthesized complexes in the present studies are more active against gram positive than gram negative bacteria. The preliminary results achieved have led us to conclude that these types of complexes should be studied in detail for their applications in diverse area.

The screening data of a particular ligand and its metal complexes show that the former has greater activity than 
the latter from the biochemical point of view. On comparing the results in general, it may be concluded that complexes containing $\mathrm{Zn}(\mathrm{II})$ and $\mathrm{Sn}(\mathrm{IV})$ have greater inhibiting power than the free ligands as compared to organotin complexes with sarcosine $[16,17]$ against all the microbes.

3.5. Antifungal Activity. The synthesized compounds (1) $-(\mathbf{6})$ and sarcosine were tested for antifungal activity by using fluconazole as standard drug against four fungal strains including A. flavus, A. niger, A. alternate, and G. lucidum by disc diffusion method [36]. The results are summarized in Table 6. It was evident from tabulated data that the sarcosine as well as the synthesized complexes exhibited, variety of fungicidal activity. Sarcosine exhibited maximum activity against $A$. flavus $(37.5 \pm 0.86)$ while complex (5) exhibited maximum activity $(39.5 \pm 1.65)$ against $G$. lucidum. Complex (2) showed the lowest inhibition zone $(19.0 \pm 1.00)$ against G. lucidum. It is noted that tributyltin complexes showed the greatest inhibitory effect against fungi as compared to other alkyl groups. Thus the presence of butyl groups in compound (5) bonded with tin atom was responsible for the rise of antifungal activity [37]. The increased activity of complexes might be due to the coordination of zinc and tin with oxygen and sulfur, respectively [38]. From the data it might be concluded that triorganotin compounds were usually more effective against the fungi than diorganotin compounds [39] in contrast to earlier reported compounds in the literature [16]. This might be due to the presence of $\mathrm{Zn}$ (II) along with $\mathrm{Sn}(\mathrm{IV})$ which enhances the fungicidal activity of triorganotin complexes.

3.6. Structure Activity Relationship. Although it is difficult to make out an exact structure-activity relationship between the antimicrobial activity and the structure of these complexes, it can possibly be concluded that the chelation as well as the addition of a substrate enhances the activity of the complexes. The variation in the toxicity of different antibacterial agents against various organisms depends on either the impermeability of the cell or differences in site of action or ability to cause mutations in the microorganism. Though the results suggest that the ligand has a remarkable toxic property, their complexes of tin inhibit the growth of microorganisms to a greater extent. This is in accordance with earlier reports [40]. Further, the greater activity of the complexes can also be explained on the basis of their higher solubility of the particles.

\section{Conclusion}

The FT-IR data of synthesized complexes clearly demonstrate that the zinc and tin become attached with the oxygen and sulphur of the ligand in a bidentate mode. In solid state, chlorodiorganotin complexes exhibit the penta/hexacoordinated geometry, whereas the triorganotin(IV) complexes show the five-coordinate geometry. Biological activity data showed that all the complexes were biologically active with few exceptions. These complexes were found to be more potent inhibitors toward fungal culture as compared to bacterial strains.

\section{Acknowledgment}

Higher Education Commission of Pakistan (HEC) is acknowledged for support under the Project no. 20-1623/R\&D/10/ 4402 .

\section{References}

[1] K. E. Appel, "Organotin compounds: toxicokinetic aspects," Drug Metabolism Reviews, vol. 36, no. 3-4, pp. 763-786, 2004.

[2] K. C. Molloy, T. G. Purcell, E. Hahn, H. Schumann, and J. J. Zuckerman, "Organotin biocides. 4. Crystal and molecular structure of tricyclohexylstannyl 3-indolylacetate, incorporating the first monodentate carboxylate group bonded to a triorganotin(IV)," Organometallics, vol. 5, no. 1, pp. 85-89, 1986.

[3] R. R. Holmes, "Organotin cluster chemistry," Accounts of Chemical Research, vol. 22, no. 5, pp. 190-197, 1989.

[4] R. Barbieri, A. Silvestri, M. T. L. Giudice, G. Ruisi, and M. T. Musmeci, "The binding of trialkyltin(IV) moieties to rat haemoglobin, and the structure of model systems, studied by tin-119 Mössbauer spectroscopy," Journal of the Chemical Society, Dalton Transactions, no. 3, pp. 519-525, 1989.

[5] S. Sadiq-Ur-Rehman, K. Shahid, S. Ali, M. H. Bhatti, and M. Parvez, "Organotin esterification of (E)-3-(3-fluoro-phenyl)2-(4-chlorophenyl)-2-propenoic acid: synthesis, spectroscopic characterization and in vitro biological activities. Crystal structure of $\left[\mathrm{Ph}_{3} \mathrm{Sn}\left(\mathrm{OC}(\mathrm{O}) \mathrm{C}\left(4-\mathrm{ClC}_{6} \mathrm{H}_{4}\right)=\mathrm{CH}\left(3-\mathrm{FC}_{6} \mathrm{H}_{4}\right)\right)\right]$," Journal of Organometallic Chemistry, vol. 690, no. 5, pp. 1396-1408, 2005.

[6] P. J. Heard, Progress in Inorganic Chemistry, vol. 53, John Wiley \& Sons, New York, NY, USA, 2005, edited by D. Karlin.

[7] S. H. L. Thoonen, B. Deelman, and G. van Koten, "Synthetic aspects of tetraorganotins and organotin(IV) halides," Journal of Organometallic Chemistry, vol. 689, no. 13, pp. 2145-2157, 2004.

[8] H. Hussain, V. U. Ahmad, I. R. Green, K. Krohn, J. Hussain, and A. Badshah, "Antibacterial organotin(IV) compounds, their synthesis and spectral characterization," Arkivoc, vol. 2007, no. 14, pp. 289-299, 2007.

[9] S. Y. Dike, J. R. Merchant, and N. Y. Sapre, "A new and efficient general method for the synthesis of 2-spirobenzopyrans: first synthesis of cyclic analogues of precocene I and related compound," Tetrahedron, vol. 47, no. 26, pp. 4775-4786, 1991.

[10] L. E. da Silva, P. T. de Sousa Jr., A. C. Joussef, C. Piovezan, and A. Neves, "Synthesis, structure and physicochemical properties of zinc and copper complexes based on sulfonamides containing 8-aminoquinoline ligands," Química Nova, vol. 31, no. 5, pp. 1161-1164, 2008.

[11] J. Anwer, S. Ali, S. Shahzadi, M. Shahid, S. K. Sharma, and K. Qanungo, "Synthesis, characterization, semi-empirical study and biological activities of homobimetallic complexes of tranexamic acid with organotin(IV)," Journal of Coordination Chemistry, vol. 66, no. 7, pp. 1142-1152, 2013.

[12] S. Jabbar, I. Shahzadi, R. Rehman et al., "Synthesis, characterization, semi-empirical study and biological activities of organotin(IV) complexes with cyclohexylcarbamodithioic acid as biological active ligand," Journal of Coordination Chemistry, vol. 65, no. 4, pp. 572-590, 2012. 
[13] H. N. Khan, S. Ali, S. Shahzadi, and M. Helliwell, "Synthesis, spectroscopy and antimicrobial activity of chloroorganotin(IV) complexes of S-donor ligand: crystal structure of chloro-t-dibutyltin[4-methyl-1-piperidine] thiocarboxylate," Russian Journal of Inorganic Chemistry, vol. 57, no. 5, pp. 665-670, 2012.

[14] F. A. Shah, A. Ali, S. Shahzadi, C. Rizzoli, and A. Ahmad, "Synthesis, spectral characterization and X-ray crystal structure of biologically active organotin(IV) 3 -[(3', $5^{\prime}$-dimethylphenylamido)]propanoates," Journal of Iranian Chemical Society, vol. 9, no. 6, pp. 923-932, 2012.

[15] M. M. Amin, S. Ali, S. Shahzadi, S. K. Sharma, and K. Qanungo, "Di- and triorganotin(IV) complexes of 2-aminobenzoic acid with and without triphenylphosphine: synthesis, spectroscopy, semi-empirical study, and antimicrobial activities," Journal of Coordination Chemistry, vol. 64, no. 2, pp. 337-350, 2011.

[16] E. Khoo, N. K. Goh, G. Eng, D. J. Whalen, and A. Hzell, "Synthesis, characterization and fungicidal activity of triphenyl derivatives of sarcosine: crystal structures of $\left[\mathrm{Ph}_{3} \mathrm{Sn}\left(\mathrm{OCOCH}_{2} \mathrm{NH}_{2} \mathrm{CHB}\right)_{2}\right] \mathrm{Cl}$ and $\left[\mathrm{Ph}_{3}\left(\mathrm{OCOCH}_{2} \mathrm{NH}_{2} \mathrm{CH}_{3}\right) 2\right] \mathrm{NCS}$," Applied Organometallic Chemistry, vol. 9, no. 8, pp. 699-706, 1995.

[17] D. Kovala-Demertzi, P. Tauridou, A. Moukarika, J. M. Tsangaris, C. P. Raptopoulou, and A. Terzis, "Synthesis and characterization of tin(IV) and organotin(IV) 1,4-dimethylpiperazine-2,5dione (cyclosarcosylsarcosine) adducts," Journal of the Chemical Society, Dalton Transactions, no. 1, pp. 123-128, 1995.

[18] L. Ronconi, C. Marzano, U. Russo, S. Sitran, R. Graziani, and D. Fregona, "Synthesis, characterization and in vitro cytotoxicity of new organotin(IV) derivatives of N-methylglycine," Journal of Inorganic Biochemistry, vol. 91, no. 2, pp. 413-420, 2002.

[19] W. L. F. Armarego and C. L. L. Chai, Purification of Laboratory Chemicals, Elsevier, Burlington, Vt, USA, 6th edition, 2000.

[20] W. D. Honnick and J. J. Zuckerman, "Diorganotin halide carboxylates, thiocarboxylates and halide haloacetates," Journal of Organometallic Chemistry, vol. 178, no. 1, pp. 133-155, 1979.

[21] E. R. T. Tiekink, "Structural chemistry of organotin carboxylates: a review of the crystallographic literature," Applied Organometallic Chemistry, vol. 5, no. 1, pp. 1-23, 1991.

[22] M. Nath, R. Jairath, G. Eng, X. Song, and A. Kumar, "Synthesis, spectral characterization and biological studies of some organotin(IV) complexes of l-proline, trans-hydroxy-l-proline and lglutamine," Spectrochimica Acta A, vol. 62, no. 4-5, pp. 1179-1187, 2005.

[23] B. S. Hammes, M. T. Kieber-Emmons, J. A. Letizia et al., "Synthesis and characterization of several zinc(II) complexes containing the bulky heteroscorpionate ligand bis(5-tert-butyl-3methylpyrazol-2-yl)acetate: relevance to the resting states of the zinc(II) enzymes thermolysin and carboxypeptidase A," Inorganica Chimica Acta, vol. 346, pp. 227-238, 2003.

[24] R. Singh and N. K. Kaushik, "Spectral and thermal studies with anti-fungal aspects of some organotin(IV) complexes with nitrogen and sulphur donor ligands derived from 2phenylethylamine," Spectrochimica Acta A, vol. 71, no. 2, pp. 669-675, 2008.

[25] H. L. Singh and J. B. Singh, "Synthesis and characterization of new lead(II) and organotin(IV) complexes of schiff bases derived from histidine and methionine," International Journal of Inorganic Chemistry, vol. 2012, Article ID 568797, 7 pages, 2012.

[26] A. Saxena, J. P. Tandon, K. C. Molloy, and J. J. Zuckerman, "Tin(IV) complexes of tridentate schiff bases having ONS donor systems," Inorganica Chimica Acta, vol. 63, no. C, pp. 71$74,1982$.

[27] A. K. Saxena, H. B. Singh, and J. P. Tandon, "Synthesis and characterization of tin(IV) complexes of azines," Synthesis Reactivity Inorganic and Metal-Organic Chemistry, vol. 10, pp. 117-136, 1980.

[28] H. O. Kalinowski, S. Berger, and S. Brown, ${ }^{13}$ C NMR Spectroskopie, Thieme, Stuttgart, Germany, 1984.

[29] S. Ali, F. Ahmad, M. Mazhar, A. Munir, and M. T. Masood, "Synthesis and spectral studies of di- and triorganotin(IV) complexes with 2-(6-methoxynaphthyl)propionic acid (naproxen)," Synthesis and Reactivity in Inorganic and Metal-Organic Chemistry, vol. 32, no. 2, pp. 357-372, 2002.

[30] J. Holeček, M. Nádvorník, K. Handliŕ, and A. Lyčka, " ${ }^{13} \mathrm{C}$ and ${ }^{119}$ Sn NMR spectra of Di- $n$-butyltin(IV) compounds," Journal of Organometallic Chemistry, vol. 315, no. 3, pp. 299-308, 1986.

[31] D. H. Williams and I. Fleming, Spectroscopic Methods in Organic Chemistry, McGraw-Hill, London, UK, 4th edition, 1987.

[32] S. S. Konstantinović, B. C. Radovanović, S. P. Sovilj, and S. Stanojević, "Antimicrobial activity of some isatin-3-thiosemicarbazone complexes," Journal of the Serbian Chemical Society, vol. 73, no. 1, pp. 7-13, 2008.

[33] R. V. Singh, P. Chaudhary, S. Chauhan, and M. Swami, "Microwave-assisted synthesis, characterization and biological activities of organotin (IV) complexes with some thio schiff bases," Spectrochimica Acta A, vol. 72, no. 2, pp. 260-268, 2009.

[34] W. Rehman, M. K. Baloch, A. Badshah, and S. Ali, "Synthesis characterization and biological study of diorganotin(IV) complexes of monomethyl phthalate," Spectrochimica Acta A, vol. 65, no. 3-4, pp. 689-694, 2006.

[35] K. K. Chaturvedi and M. Goyal, "Antibacterial studies of 7-( $\alpha$-substituted sulphonamido)methyl- and 7-( $\alpha$-substituted sulphonamido)phenyl-8-hydroxyquinolines," Journal of the Indian Chemical Society, vol. 61, no. 2, pp. 175-176, 1984.

[36] H. L. Singh, B. Khungar, U. D. Tripaathi, and A. K. Varshney, "Spectral and antimicrobial studies of organotin(IV) complexes of bidentate schiff bases having nitrogen and sulphur donor systems," Main Group Metal Chemistry, vol. 24, no. 1, pp. 5-12, 2001.

[37] T. R. Fritsche, P. F. McDermott, T. R. Shryock, and R. D. Walker, "Agar dilution and disk diffusion susceptibility testing of Campylobacter spp.," Journal of Clinical Microbiology, vol. 45, no. 8, pp. 2758-2759, 2007.

[38] M. Jabeen, S. Ali, S. Shahzadi et al., "Homobimetallic complexes of ligand having $\mathrm{O}$ and $\mathrm{S}$ donor sites with same and different di- and trialkyl/aryltin(IV) moiety their synthesis, spectral characterization and biological activities," Journal of Iranian Chemical Society, vol. 9, no. 3, pp. 307-320, 2012.

[39] S. Shahzadi, K. Shahid, S. Ali, and M. Bakhtiar, "Characterization and antimicrobial activity of organotin(IV) complexes of 2-[(2',6'-diethylphenylamido $)]$ benzoates and 3-[(2',6'-diethylphenylamido)]propanoates," Turkish Journal of Chemistry, vol. 32, no. 3, pp. 333-353, 2008.

[40] M. Ashfaq, M. I. Khan, M. K. Baloch, and A. Malik, "Biologically potent organotin(IV) complexes of 2-maleimidoacetic acid," Journal of Organometallic Chemistry, vol. 689, no. 1, pp. 238245, 2004. 

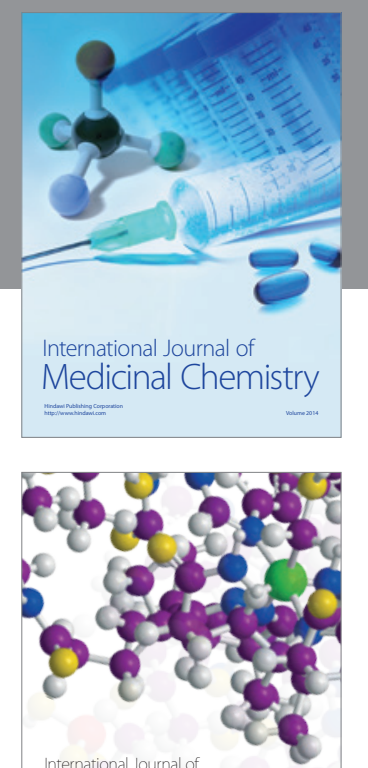

\section{Carbohydrate} Chemistry

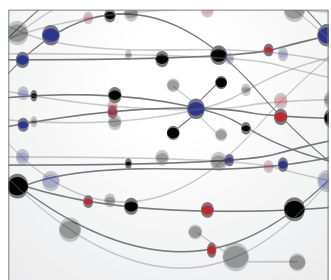

The Scientific World Journal
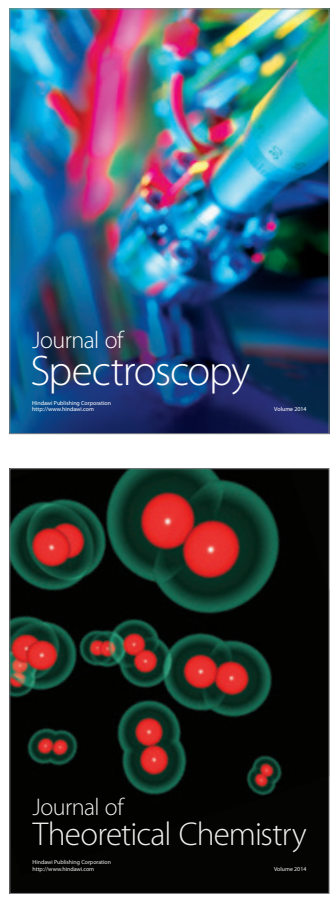
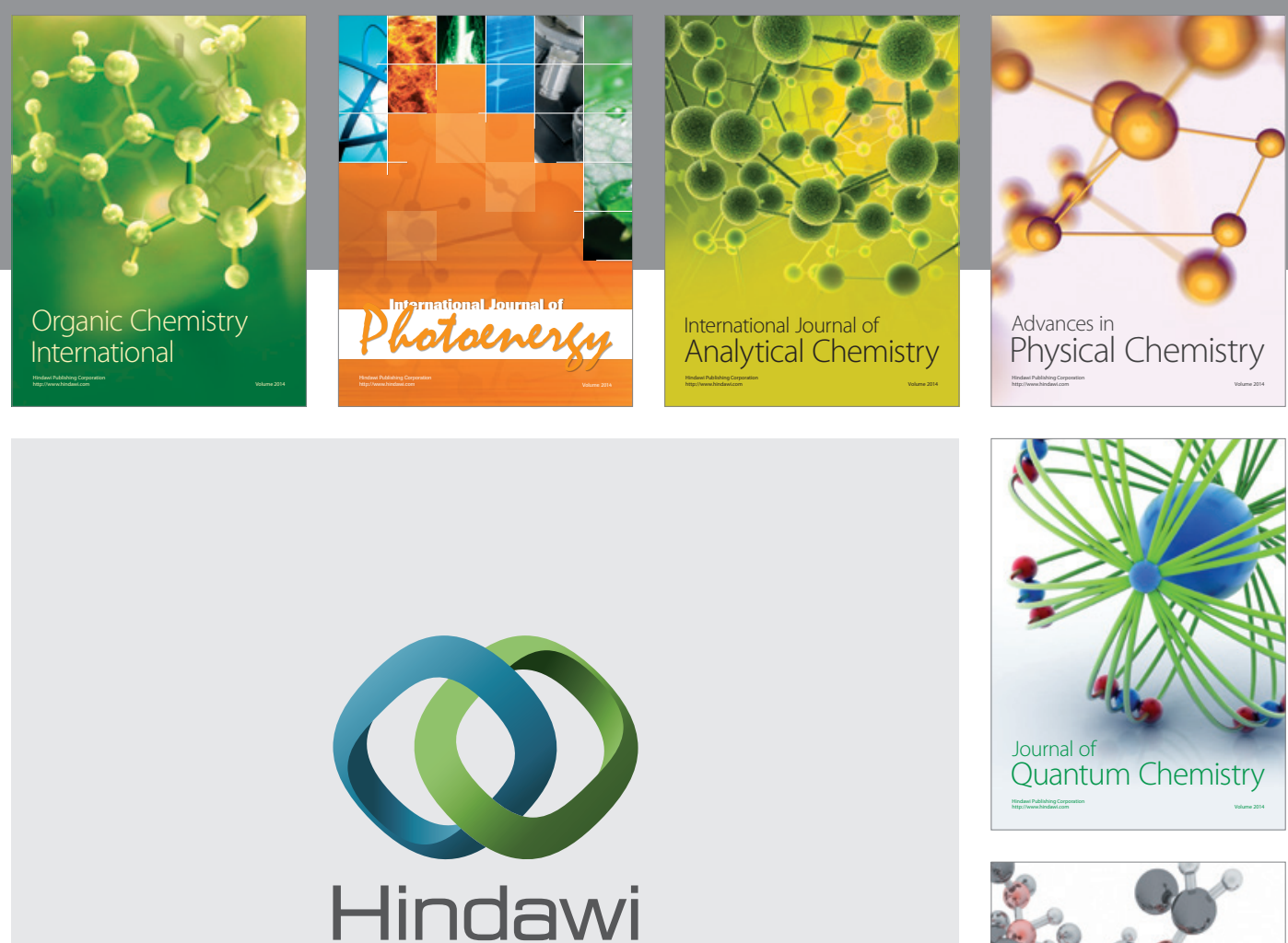

Submit your manuscripts at

http://www.hindawi.com

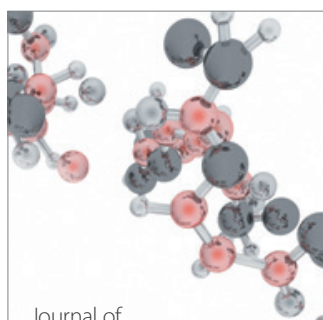

Analytical Methods

in Chemistry

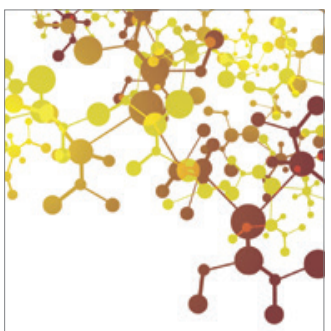

Journal of

Applied Chemistry

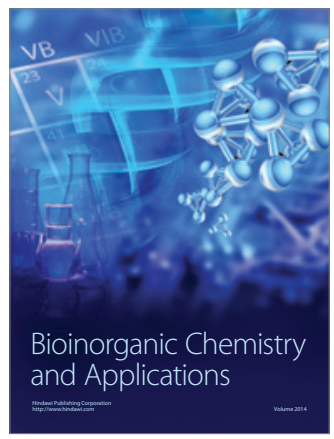

Inorganic Chemistry
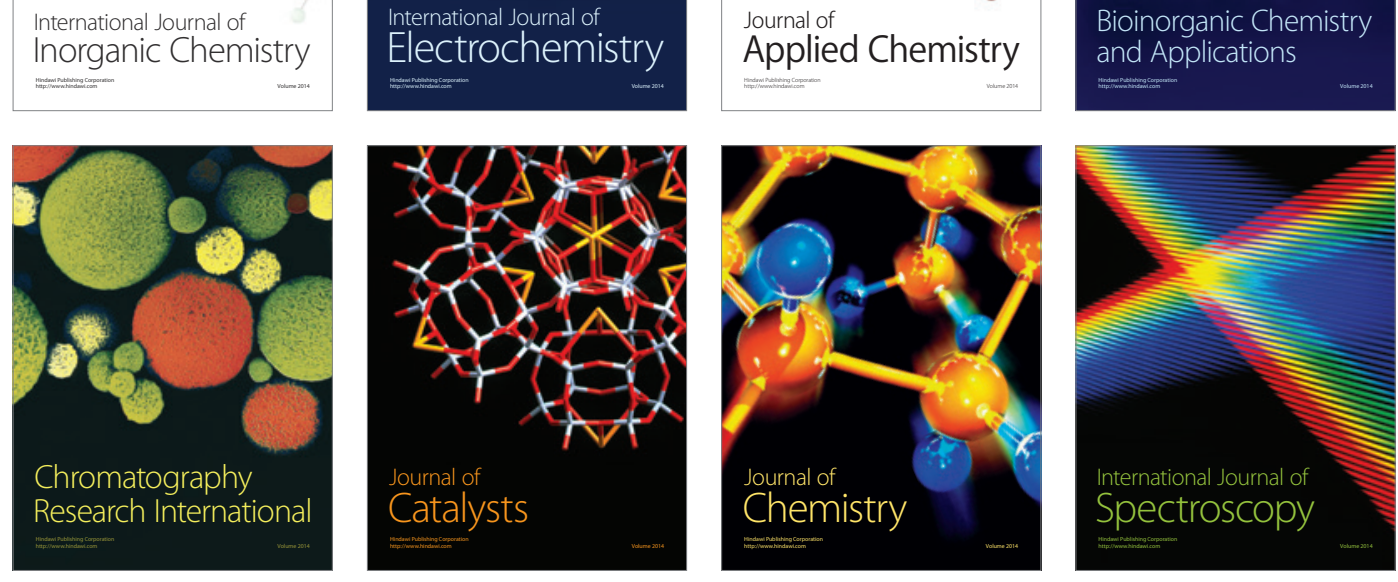